\title{
The Mediating Role of Organizational Commitment in the Effect of Perception of Commitment to Change on Job Satisfaction ${ }^{1}$
}

\author{
Faruk Kerem ŞENTÜRK (iD) a, Mehmet ERTEM (iD) a \\ a Düzce University, Faculty of Business Management, Depart. of Business Administraiton, Düzce, Turkey. keremsenturk@duzce.edu.tr \\ b Yozgat Bozok University, Faculty of Economics and Administrative Sciences, Yozgat, Turkey. mehmet.ertem@bozok.edu.tr
}

\begin{tabular}{ll}
\hline ARTICLE INFO & ABSTRACT \\
\hline Keywords: & $\begin{array}{l}\text { Purpose }- \text { The period we are in forces individuals, societies, and naturally businesses to change. } \\
\text { Businesses experience many changes together in terms of technology, organizational culture and } \\
\text { structural features. These change processes create positive or negative effects on the satisfaction of } \\
\text { employees. Top administrations generally have to be aware of the importance of voluntary participation } \\
\text { Job Satisfaction }\end{array}$ \\
$\begin{array}{l}\text { Commitment to Change } \\
\text { in the process of change to take the support of the followers and to overcome the process without any } \\
\text { problems. The mediating role of organizational commitment that manifests in different ways under the } \\
\text { effect of the perception of affective commitment to the change on job satisfaction have been tried to be } \\
\text { determined. }\end{array}$
\end{tabular}

Received 5 January 2021

Revised 16 March 2021

Accepted 25 March 2021

Design/methodology/approach - Within the scope of the study in which 372 personnel of Yozgat Provincial Health Directorate were considered as the population, data were obtained from a sample of 196 people. Due to the changes in the structuring processes of the provincial organization of the Ministry of Health, the employees of the Provincial Health Directorate were included in the research process. The quantitative method was preferred and the questionnaire was used as data collection technique.

Article Classification: Research Article
Findings - As a result of the research, it was determined that affective and normative organizational commitment had a mediating effect on the relationship between affective commitment to change and job satisfaction. Continuance commitment does not have a mediating effect on the relationship between the perception of affective commitment to change and job satisfaction.

Discussion - It is an undeniable necessity to get the support of organization employees in the process of change and to ensure that they have faith in this process. However, another important issue is how employees develop a commitment to their organizations when they set aside the process of change in their minds. Organizations should focus on the ways of making their employees dependent on the organization rather than making them dependent on change. Especially in change processes that concern the whole organization, motivating employees to develop beliefs and support for the said change without examining and analyzing the types and levels of commitment to the organization, or providing this with pressure, can cause the failure of change processes that require very serious labor and capital.

\section{Introduction}

The famous futurist writer Alvin Toffler, in his work "Third Wave", claims that agricultural reform initiated the first wave of transformative change in human history 10.000 years ago and the industrial revolution 300 years ago started the second wave of change and we are feeling the impact of change as the third wave today (Toffler, 2018). From this point of view, it is understood that the change and the factors affecting the change maintain their existence throughout the historical process. People, societies, and organizations that form the economic foundations of societies also take their share from the waves of change experienced. It is observed that the waves of change that took place especially after the industrial revolution affect the organizational structures, whose number has increased rapidly, at a higher level.

In the classical period symbolized by Taylorism, organizations were seen as machines and it was argued that once organizations were established in the best way, they would function spontaneously just like machines. Based on the failure of closed machine organizations, it is seen that the understanding of the organic

1 This study is an improved version of the paper presented at the 28th National Management and Organization Congress held between September 3-5.

\section{Suggested Citation}

Şentürk, F.K., Ertem, M. (2021). The Mediating Role of Organizational Commitment in the Effect of Perception of Commitment to Change on Job Satisfaction, Journal of Business Research-Turk, 13 (1), 760-771. 


\section{F. K. Şentürk - M. Ertem 13/1 (2021) 760-771}

organization that approaches organizations as living systems has come into existence and the preference has changed from the human-system dual to the human. This change has triggered the emergence of approaches such as contingency, organizational ecology, institutionalization, and resource dependency. As a matter of fact, due to the coexistence of versatility and complexity and characteristic of this new era, it is seen that the validity of the theories in the hegemony of the paradigms given above loses their effects over time.

The point that needs to be paid particular attention to in all these processes of change is the knowledge that while it was seen that the change took centuries and was less directional in previous processes, the rate of change increased enormously in the current period and took place in multiple ways. Accordingly, it has been observed that concepts such as strategy, sustainability, and flexibility are mostly used in the managerial area, especially in recent years. Therefore, organizations have to sense, learn, understand, interpret changes happening in the environment for different reasons, and develop their ability to adapt to change.

Within the scope of the research carried out with this process, it was aimed to determine the mediating role of organizational commitment in the effect of the commitment to change on job satisfaction. Employees' belief and ownership of the change process will also increase the level of satisfaction they get from the job. At this point, it is important to determine the mediating role of organizational commitment levels in different forms (affective, continuance, and normative commitment) to sustain the process more effectively.

\section{Theoretical Framework}

According to the definition of the Turkish Language Association (TLA), the change is defined as "The whole of the changes in a time period, exchange, barter, interchange" (TLA, 06.02.2020). Change can occur both at the individual level and at the level that includes an organization. In addition to its potential to produce positive results, it can also bring many negative consequences. In this context, it is important from where to look at the concept of change and how to draw and evaluate its boundaries.

Organizations face with the situation of adapting to different conditions every year, otherwise, they lose their struggle to survive. Zincirkıran and Keser (2018) state six factors that deeply affect the change process of organizations. These factors are listed as developments in technology, activities of competitors, economic crises in the world, changes in customer demands and expectations, legal regulations, and political developments at the global level. While the specified factors include elements that can be described as external, many factors within the organization can also shape the change process. In this context, Özkalp and Kurel (2005) state that the change will occur if the values and beliefs of the people who participate in the change process are in the direction that will meet the costs at the time of change. However, more importantly, when the dissatisfaction rate within the organization, the existence of a positive and desired alternative, and the existence of a plan that can realize such an alternative are evaluated together, it is stated that the rate of successful realization of the change is high.

Considering organizational change independently from the individuals that make up the organization creates an obstacle to understand the phenomenon in a holistic way. According to the social exchange theory, which is defined as the act of giving labor to the organization in return for material or intangible benefits, the relationship between employees and the organization will continue as long as both sides benefit from this and the sides will fulfill their obligations (Sezgin et al., 2016; Bartlett, 1999). According to the psychological contract theory, an organization has a set of unwritten expectations that always operate between each member and various managers and others in that organization (Schein, 1980). According to both theories, there are mutual relations between the employee and the organization, including expectations or actions based on labor. In this context, a change process where employees are not involved, or their reactions are not taken into account has the potential to fail.

Koçel (2005) draws attention to issues such as the mentality of the employees, their perspective on creativity and innovation, and their relations with the organization for occurring the change. In this context, the necessity of handling the psychological (relationships that bind and make the employee loyal to the organization) and social aspects (relations between the employee's own culture and value structures and the organization's culture) of the employee in the process of change is emphasized. Otherwise, there will be a problem such as 


\section{F. K. Şentürk - M. Ertem 13/1 (2021) 760-771}

an inability to find answers to the questions that arise in the minds of employees during the change process, and this will create resistance to change that is frequently encountered in the change process.

When the reasons of the employees to resist change are examined, they are discussed under the headings of rational reasons such as; dismissal, loss of economic security, loss of status, conflict in economic and social values such as loss of power in resource distribution, loyalty to the group, change in the way of doing business, uncertainty, lack of information, belief that change is wrong, different goals and evaluation forms, cost of change, making an additional effort, judgments developed for those who make the change, the risk that expertise in a subject is deemed unnecessary after the change (Tunçer, 2013). As it is seen, many of the reasons for resistance to change are directly or indirectly related to employees in terms of content. In this direction, the commitment of employees to the organization and to change plays an important role in the realization of the change process and can affect their job satisfaction.

Although there are many elements in the organization that will encourage the employee to believe in change and support it, especially the development of a belief and commitment to the change should be seen as a facilitating factor. The concept of commitment to change is defined by Herscovitch and Meyer (2002) as "the mental power that enables an individual to act within certain behavioral patterns for the successful implementation of a change initiative". The authors, who stated that this power will be revealed in three ways as affective, continuance, and normative, defined the affective commitment to change discussed within the scope of the study as "the desire to support change based on the belief that it is beneficial". Meyer et al. (2007) state that employees with high commitment to change believe in change and want to contribute to the process, and willing to do more than necessary and exhibit altruistic behaviors. Holt et al. (2007) state that readiness for change is a multidimensional process influenced by the belief that employees can implement the proposed change, change is beneficial for the organization, the leader depends on the foreseen change and the change will also benefit the members of the organization. Lines (2004) states in his study that the participation of those affected by a change will decrease organizational resistance and create a higher psychological commitment among the employees.

On the other hand, the question of what kind of a bond the employee has developed towards the organization should be answered especially in the change processes. Some researchers claim that there is no human factor or structure that affects organizational outcomes more than organizational commitment (Cater \& Zabkar, 2009). Organizational commitment is basically shaped on three principles (Mowday et al., 1979: 226):

- Strong acceptance and belief in the organization's values and basic beliefs

- Willingness to make a significant effort on behalf of the organization

- Have a strong passion for maintaining organization membership.

Accordingly, employees who show commitment to the organization are characterized as loyal and efficient members of the organization (Furtmueller et al., 2011). According to the definition made by Porter et al. (1973), organizational commitment is "the feeling that an individual feels to belong to a certain organization and to consider himself a part of the organization". The authors expressed this commitment under three factors: belief in accepting organizational goals and objectives, willing to voluntarily work more for the organization, and desire to be permanent in the company. Meyer and Allen (1991) stated in their study that organizational commitment should be handled in three different dimensions: establishing an emotional bond with the organization (affective), perceived cost associated with leaving the organization (continuation) and obligation to stay in the organization (normative). Affective commitment means that the employee feels emotionally connected to his organization and identifies himself with the organization, continuance commitment expresses the individual's willingness to stay in this organization due to the acceptance of the costs that will arise in case of leaving the job and the personal investments made in the organization, normative commitment, on the other hand, states that internalized normative pressures act to meet organizational goals and interests, and individuals act only because they believe that it is the "right" and moral thing to do (Meyer et al., 1998; Meyer et al., 1993; Allen \& Meyer, 1990). All three components of organizational commitment differ in terms of being independent from each other and conceptual content among employees (Valaei \& Rezaei, 2016).

The concept of job satisfaction, which is formed as a result of evaluating the characteristics of the job and explains a positive feeling about the job, can be described as a positive organizational output desired by all organizations (Robbins \& Judge, 2013). Spector (1997) explains job satisfaction as "the level of people loving 


\section{F. K. Şentürk - M. Ertem 13/1 (2021) 760-771}

what they do" and a collection of feelings he felt about the various aspects of the job. While job satisfaction aims to measure whether employees are generally satisfied with their jobs according to the global approach, the feature approach examines more than one factor (wage, career opportunities, working conditions, etc.) and tries to measure employee satisfaction in-depth (Keser \& Kümbül Güler, 2016). Studies have shown that employee job satisfaction is not an independent concept because it is intertwined with other issues (Reid et al., 2008; Falkenburg \& Schyns, 2007). In the scope of the research, an evaluation was made on the scale that addressing general satisfaction developed by Hackman and Oldham (1975). In this context, employees should have an affective commitment to balance job satisfaction in change processes but in order to put this on a more solid basis, a research model was built based on the idea that organizational commitment plays a mediating role in the mentioned relationship.

Weiner (2009) states that, on the basis of social cognitive theory, when the readiness for organizational change is high, the members of the organization tend to make more efforts to initiate change, support change, and for obstacles or setbacks encountered during implementation. In the study carried out by Herscovitch and Meyer (2002), it is revealed that affective commitment to change has a positive relationship with affective organizational commitment and a negative relationship with continuance commitment, but it does not have a significant relationship with normative commitment. Yousef (2000), on the other hand, states in his study that emotional perception towards change increases affective commitment.

Wulandari et al. (2015) state that there is a significant relationship between commitment to change and job satisfaction. Rafferty and Griffin (2006) state that employees' perception of change is a concept related to job satisfaction.

Gomes (2009) stated that organizational commitment has a mediating effect on the relationship between the perceived effectiveness of organizational change processes and job satisfaction. Therefore, it is stated that the perception of organizational change processes as effective by employees creates an affective bond with the organization and this leads to job satisfaction.

The hypotheses wanted to be tested within the scope of the model are as follows:

H1: Affective commitment has a mediating effect on the relationship between the perception of affective commitment to change and job satisfaction.

$\mathrm{H} 2$ : Continuance commitment has a mediating effect on the relationship between the perception of affective commitment to change and job satisfaction.

H3: Normative commitment has a mediating effect on the relationship between the perception of affective commitment to change and job satisfaction.

\section{Method}

The quantitative method was preferred in terms of the route followed in the study. The questionnaire was used as data collection technique. Information about the scales, universe, and sampling, and research model used in the research are given below.

\section{Measures}

To measure job satisfaction, a one-dimensional 5-statement scale with a Cronbach's alpha score of .87, which was developed by Hackman and Oldham (1975) and adapted into Turkish by Şeşen and Basım (2010) and used by Şevik (2019), was used. To measure organizational commitment, the three-dimensional (affective, continuance, normative commitment) scale developed by Meyer et al. (1993) and used by Darican (2019) with 18 expressions of Cronbach's alpha score between .91 and 92 was used. To measure commitment to change, the scale developed by Herscovitch and Meyer (2002) has three sub-dimensions of 18 expressions, and only 6item affective commitment to change sub-dimension was used. The scale was adapted to Turkish by Toprak and Aydin (2015) and has a Cronbach's alpha score of .85.

\section{Population and Sample}

The provincial organization of the Ministry of Health has undergone two important administrative change processes within the scope of the "Health Transformation Reform Package" in the last decade. The first of these changes took place with the Decree-law No. 663 (2011). Authorities within the Provincial Health Directorate 


\section{F. K. Şentürk - M. Ertem 13/1 (2021) 760-771}

were divided between the two newly established presidencies (Public Health Presidency and Public Hospitals Institution Presidency) and a kind of triangulation situation actually emerged. Afterwards, this three-headed situation, which emerged with the Decree-law No. 694 (2017), was eliminated and reverted to its former state, by collecting the shared powers and responsibilities within the Provincial Health Directorates. These radical changes experienced in the provincial organization of the Ministry deeply affected not only the top managers but also the middle and lower-level employees operating in the organization. In this context, conditions such as the physical environment in which many employees work, hierarchical position, the unit they work in, their colleagues, and the supervisor they are responsible for have changed. Also, it is believed that it is necessary and important to conduct a research focusing on employee perceptions regarding these radical organizational changes experienced in the Yozgat Provincial Directorate of Health and that doing such a study will have a significant meaning in terms of the relevant literature. The data obtained within the scope of the research were collected between 20 October and 20 December 2019.

The population of the research consists of 372 personnel affiliated with the Yozgat Provincial Directorate of Health. Since it could not be reached the whole population, the sampling method was used. To calculate the sample size, "n = N.t'.p.q / $d^{2}$. (N-1) + t.p.q" formula was applied (Karagöz, 2014) and the number to be reached was determined as 190. 250 questionnaires were distributed in total, 200 questionnaires were collected, 4 questionnaires were eliminated for different reasons and the analyses were conducted with 196 questionnaires.

\section{Research Model}

The main purpose of the research is to reveal the mediating role of organizational commitment in the effect of commitment to change on job satisfaction. Some conditions need to be met to be able to talk about the mediation effect.

Baron and Kenny (1986) defined these steps as follows (Gürbüz \& Bekmezci, 2012; Koç et al., 2014; Özbek et al., 2014)

1. The independent variable should have a significant effect on the dependent variable.

2. The independent variable should have a significant effect on the mediator variable.

3. The mediator variable should have a significant effect on the dependent variable.

4. When the mediator variable is included in the regression analysis in the second step; if there is an insignificant relationship between the independent variable and the dependent variable, full mediation effect occurs, and if the relationship between the independent variable and the dependent variable decreases, a partial mediation effect occurs.

However, when the literature is examined, it is seen that the steps, which developed by Baron and Kenny (1986) towards mediation analysis, have been seriously criticized (Gürbüz, 2019; Hayes, 2018; Fritz \& MacKinnon, 2007; Hayes \& Rockwood, 2017; Preacher \& Hayes, 2004). In this context, the mediation analysis steps put forward by Gürbüz (2019: 57-58) in line with the criticism, discuss the first three steps of Baron and Kenny (1986), however, he states that the insignificance of these steps does not mean that there is no mediating effect. In the last step, he states that the mediating effect should be tested with the bootstrap technique instead of the Sobel test.

In this context, the model supported by the literature review is as follows.

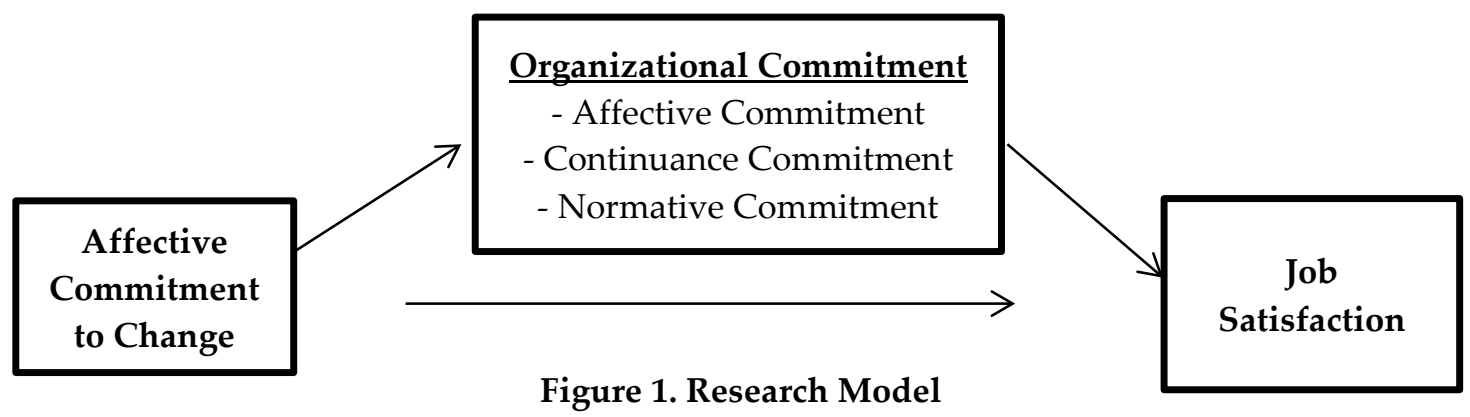




\section{Findings}

In this part of the study, descriptive statistics for variables, information about participants, and findings of testing hypotheses are shared.

\section{Descriptive Statistics}

Within the scope of descriptive statistics, information average of variable, standard deviation, reliability coefficients, and number of questions are shared for each variable.

Table 1. Means, Standart Deviations and Reliabilities of Variables

\begin{tabular}{|c|c|c|c|c|c|}
\hline \multicolumn{2}{|l|}{ Variables } & Mean & Std. Deviation & $\begin{array}{c}\text { Number of } \\
\text { Questions }\end{array}$ & $\begin{array}{c}\text { Cronbach Alfa } \\
\text { Coefficient }\end{array}$ \\
\hline \multicolumn{2}{|c|}{ Affective Commitment to Change } & 3.19 & .81 & 6 & .74 \\
\hline \multicolumn{2}{|l|}{ Job Satisfaction } & 3.59 & .90 & 5 & .84 \\
\hline \multirow{3}{*}{$\begin{array}{l}\text { Organizational } \\
\text { Commitment }\end{array}$} & Affective & 3.41 & .71 & 6 & .58 \\
\hline & Continuance & 3.37 & .81 & 6 & .73 \\
\hline & Normative & 3.31 & .90 & 5 & .62 \\
\hline
\end{tabular}

As a result of the analyses carried out, it is seen that the means for the variables are realized as a medium level of participation. Özdamar (1999) states the criterion values for the reliability coefficient as follows; not reliable in the range $0.00<\alpha<0.40$, low reliable in the range of $0.41<\alpha<0.60$, moderately reliable in the range of $0.61<\alpha$ $<0.80$, and highly reliable in the range of $0.81<\alpha<1.00$. Looking at the given criteria, it can be said that the job satisfaction scale is high, the scales of affective commitment to change, normative and continuance commitment are at a moderate level, and the affective commitment scale is low. In the normative commitment scale consisting of 6 statements under normal conditions, the 18th item was removed due to lowering its reliability, and the scale was used in the analysis with its final version of 5 statements and .62 cronbach alpha score.

\section{Information about the Participants}

When the information obtained about the participants was evaluated, it has been seen that $52.6 \%$ of the participants are male, more than half $(64.3 \%)$ are working as health officers and civil servants, the age range is $24-34(23.3 \%), 35-44(40.4 \%)$ and (\%36.3) 45 and over. When their duration of working in the profession is evaluated, it has been determined that $34.6 \%$ of the participants have been operating in the profession for 110 years, $31.9 \%$ between $11-20$ years and $33.5 \%$ for 21 years or more. Also, when the working periods in the current institution are considered, it is seen that the majority of them $(63.7 \%)$ worked in the same institution between 1-10 years. When the former institutions before the change process (institutional merger) have been discussed, it has been seen that 27.4\% worked in the Provincial Health Directorate, 33.2\% in the Public Health Directorate, $14.2 \%$ worked in the Public Hospitals General Secretariat and the rest worked in different institutions.

\section{Findings on Hypotheses}

In this part of the study, the regression analyzes performed to test the hypotheses put forward are shared. Regression analyzes based on the bootstrap method have been carried out to test the mediation effect. Analyzes have been performed by using Process macro developed by Hayes (2018). Bootstrap technique and 5000 resampling option have been preferred in the analyses. This method shows whether the indirect effect is significantly based on the reliance intervals. If there is "0" in the values in the lower and upper reliance intervals, the indirect effect is considered to be insignificant (İmamoğlu and Turan, 2019). While interpreting the effect sizes, the $\mathrm{K}^{2}$ (Fully standardized effect) value is generally used; if it is close to $\mathrm{K}^{2}=.01$, it is interpreted as a low effect, if it is close to $\mathrm{K}^{2}=.09$, it is interpreted as a medium effect, if it is close to $\mathrm{K}^{2}=.25$, it is interpreted as a high effect (Preacher \& Kelly, 2011; Gürbüz, 2019).

The results of the analysis carried out in this direction are shared as follows. 
F. K. Şentürk - M F.rtem 1.3/1 (ग021) 760-771

$\mathrm{R}^{2}=.110$

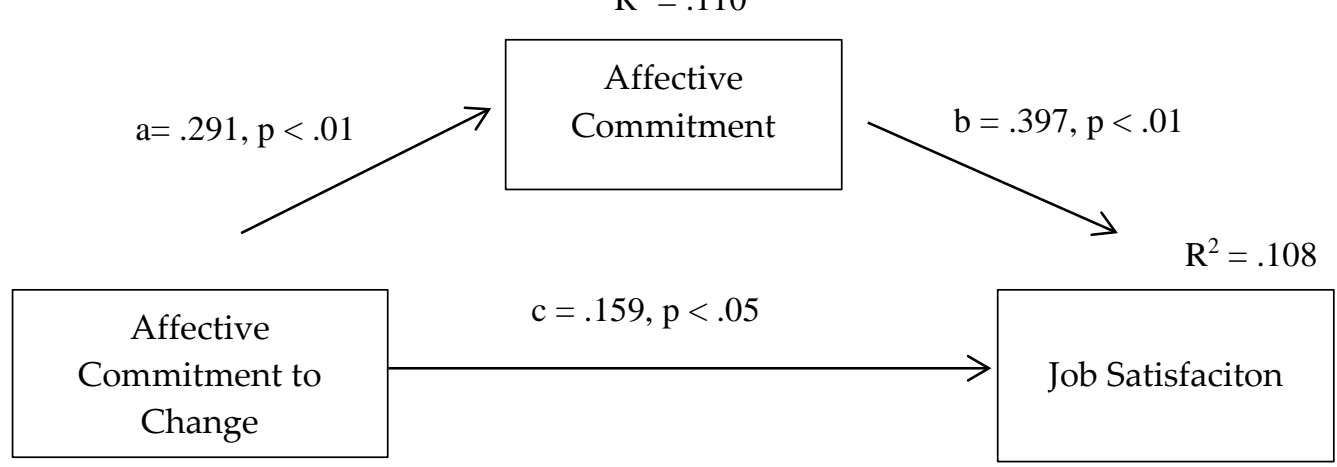

Direct Effect $\left(c^{\prime}\right)=.044, \mathrm{p}>0,5$

Indirect Effect $=.116, \% 95$ CI $[.05, .20]$

Figure 2. Mediation Analysis I

As a result of the analysis carried out, firstly the steps specified in the method section have been checked to test the mediation variable. It has been seen that affective commitment to change has a significant and positive effect on job satisfaction $(=.159, \mathrm{p}<0.05)$. It is seen that affective commitment to change affects affective commitment dimension significantly and positively $(=.291, \mathrm{p}<0.001)$. It is seen that affective commitment, which is the mediator variable, affect job satisfaction, the dependent variable, significantly and positively ( $\beta$ $=.397, \mathrm{p}<0.001$ ). Finally, it is seen that the indirect effect of affective commitment to change dimension on job satisfaction is significant, and affective commitment mediates this relationship ( $\beta=.116,95 \%$ CI $[.04, .20]$ ). There is no 0 value in the reliance intervals obtained as a result of the analysis. The total standardized effect size of the mediation effect is $\left(\mathrm{K}^{2}\right) .104$ and it can be said that this value is close to the medium value. Therefore, the $\mathrm{H} 1$ hypothesis is accepted.

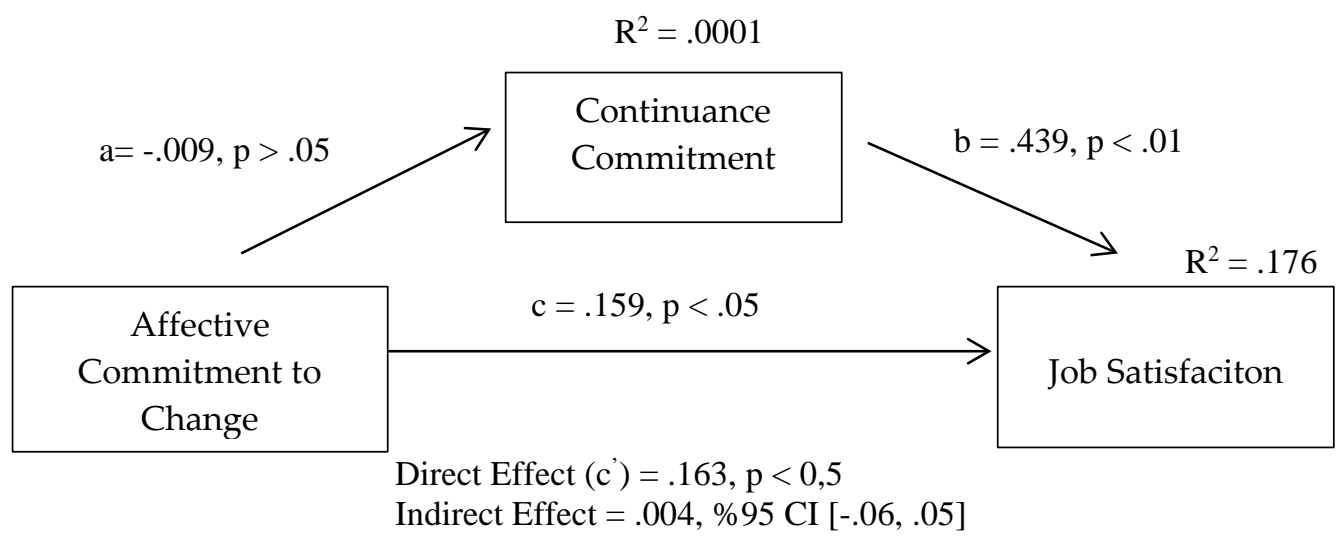

Figure 3. Mediation Analysis II

As a result of the analysis carried out, firstly the steps specified in the method section were checked to test the mediation variable. It is seen that affective commitment to change has a significant and positive effect on job satisfaction $(=.159, \mathrm{p}<0.05)$. It is seen that affective commitment to change negatively affects the continuance commitment dimension, but this effect is not statistically significant $(\beta=-.009, p>0.05)$. It is seen that continuance commitment, the mediator variable, appears to have a significant and positive effect on job satisfaction, which is the dependent variable $(=.439, \mathrm{p}<0.001)$. Finally, it is seen that the indirect effect of affective commitment to change dimension on job satisfaction is not significant and continuance commitment does not mediate this relationship ( $\beta=.004,95 \%$ CI $[-.06, .05])$.

Therefore, the $\mathrm{H} 2$ hypothesis is rejected. 


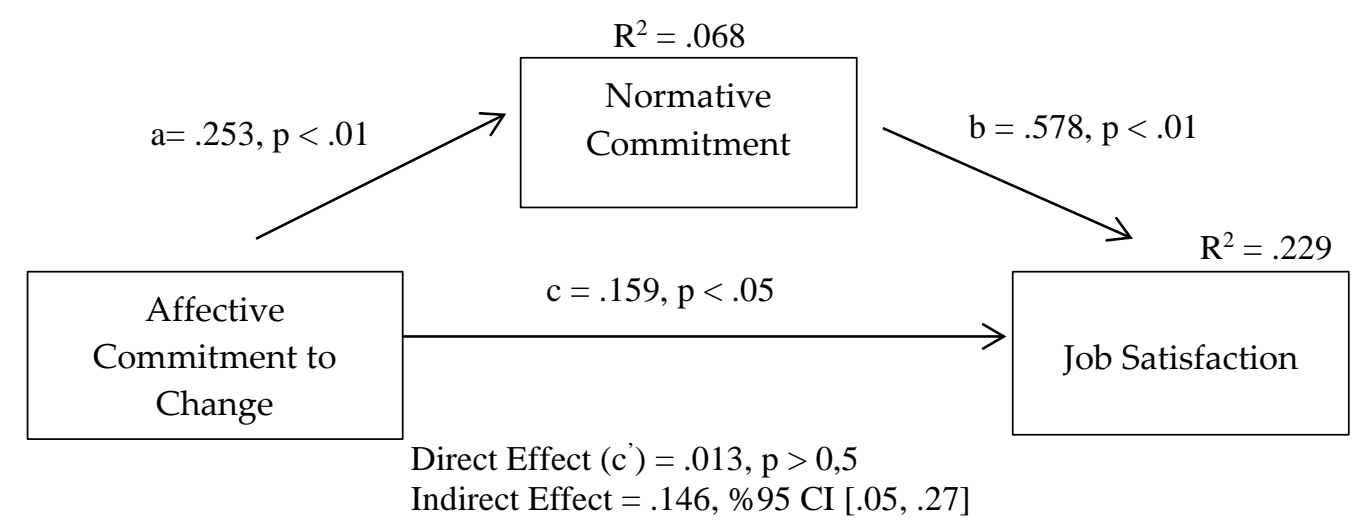

Figure 4. Mediation Analysis III

As a result of the analysis carried out, firstly the steps specified in the method section were checked to test the mediation variable. It is seen that affective commitment to change has a significant and positive effect on job satisfaction $(=.159, \mathrm{p}<0.05)$. It is seen that affective commitment to change has a significant and positive effect on the normative commitment dimension $(=.253, \mathrm{p}<0.01)$. It is seen that the mediator variable, normative commitment, significantly and positively affect job satisfaction, which is the dependent variable $(=.578, \mathrm{p}$ $<0.01)$. Finally, it is seen that the indirect effect of affective commitment to change dimension on job satisfaction is significant, and normative commitment mediates this relationship ( $\beta=.146,95 \% \mathrm{CI}[.05, .27])$. There is no 0 value in the reliance intervals obtained as a result of the analysis. The fully standardized effect size of the mediation effect is $\left(\mathrm{K}^{2}\right) .131$, and it can be said that this value is close to the medium value. Therefore, the H3 hypothesis is accepted.

\section{Conclusion and Discussion}

Change processes are generally met with reaction and resistance in terms of evoking a sense of going beyond the usual in the human mind. People cannot accept the idea that their physical and mental efforts for many years to achieve a certain position, title or success will be wasted by being caught in a wave of change. On the other hand, there may be those who see these processes as an opportunity to improve themselves, learn new things, and rise. Therefore, the primary goal in change processes should be to understand the change in all its details and share this information with the people that we think will be affected by the change. Only having knowledge is insufficient in this process, also it is important to evaluate the mental and emotional states of individuals and to make moves in this direction. The complex structure of employee satisfaction with its cognitive, emotional and behavioral dimensions requires more attention to the issue. Therefore, perception towards change affects the satisfaction of the employees either positively or negatively.

It is an undeniable necessity to get the support of organization employees in the process of change and to ensure that they have faith in this process. However, another important issue is how employees develop a commitment to their organizations when they set aside the process of change in their minds. Within the scope of the study, it has been aimed to determine the mediating effects of the perception of commitment to the organization that develops in different ways in the effect of the perception of affective commitment to change on job satisfaction.

According to the results obtained, employees' desire to provide support for the change and the belief that change is beneficial (affective commitment to change) in an enterprise in the change process has an impact on job satisfaction, but having an affective bond with the organization, that is, identifying himself with the company or having belief on developing behavior (normative commitment) to meet organizational goals and interests due to internal moral pressures has a more important effect on their satisfaction. In this context, organizations should focus on the ways of making their employees dependent on the organization rather than making them dependent on change. This commitment appears as both affective and normative commitment.

Jaros (2010) states that commitment to change is accepted as a key psychological mechanism that connects organizational efforts to implement planned change and behaviors of employees. Parish et al. (2008) have stated that attention should be paid to the adaptation of employees to the organization's vision, the quality of manager-employee relations and the employee role in the company to achieve commitment to change. Shin et 


\section{F. K. Şentürk - M. Ertem 13/1 (2021) 760-771}

al. (2015) stated that commitment to the process before and after the change starts should be distinguished from each other, because there are significant differences between employees' reactions to change by exchanging ideas about change plans and their reactions to implementing the change plan directly without exchanging ideas. In this context, it can be stated that organizational commitment has a critical role in this relationship. The commitment of the employees to both their organizations and their managers is a support mechanism needed in change processes. The tendency of job satisfaction to decrease, especially in the processes experienced, can be interpreted as the need for more employee commitment.

On the other hand, no significant mediating effect of continuance commitment has been found in the relationship between affective commitment to change and job satisfaction. When the direct effects of types of organizational commitment on job satisfaction are examined, normative commitment $\left(R^{2}:\right.$.228) comes first, followed by continuance commitment $\left(R^{2}: .155\right)$ and affective commitment $\left(R^{2}: .106\right)$. Another point that should be considered in this context is that the effect of affective commitment on job satisfaction is lower than other commitment types. Accordingly, although continuance commitment does not have a mediating effect, it has an explanatory effect of $16 \%$ on job satisfaction. In the current century, it is seen that many stereotypical information such as working hard equals much efficiency has collapsed, and even companies such as Google (Forbes, 10.02.2020), which are the most desired to work in the world, have a remarkable personnel turnover rate (Business Insider, 10.02.2020). It should be kept in mind that even though businesses desire a commitment on the axis of affective commitment, employees can be efficient in different types of commitment.

Especially in change processes that concern the whole organization, motivating employees to develop beliefs and support for the said change without examining and analyzing the types and levels of commitment to the organization, or providing this with pressure, can cause the failure of change processes that require very serious labor and capital.

In this context, subjects such as HR practices, leader behaviors, organizational policies, organizational communication mechanisms, organizational culture, perception of organizational justice, career commitment in terms of their effects on the change process appear as variables that can be used in new studies in the context of their direct and indirect effects.

\section{REFERENCES}

Allen, N.J. \& Meyer, J.P. (1990). The Measurement and Antecedents of Affective, Continuance and normative commitment to the Organization. Journal of Occupational Psychology, 63(1), 1-18.

Baron, R.M. \& Kenny, D.A. (1986). The moderator-mediator variable distinction in social psychological research: Conceptual, strategic, and statistical considerations. Journal of Personality and Social Psychology, 51(6), 1173-1182.

Bartlett, K.R. (1999). The Relationship Between Training and Organizational Commitment in The Health Care Field. The Degree of Doctor of Philosophy, The University of Illınois, Urbana.

Business Insider. 16.04.2018. "Silicon Valley techies get free food and dazzling offices, but they're not very loyal - here's how long the average employee stays at the biggest tech companies", https://www.businessinsider.com/average-employee-tenure-retention-at-top-tech-companies-2018-4, Erişim Tarihi: 10.02.2020.

Cater, B. \& Zabkar, V. (2009). Antecedents and Consequences of Commitment in Marketing Research Services: The Clients' Perspective. Industrial Marketing Management. 38(7), 785-797.

Darıcan, Ş. (2019). Hastanelerde Personel Güçlendirmenin İş Tatmini, Yöneticiye Güven Ve Örgütsel Bağlllık Üzerine Etkisi Ve Buna Yönelik Bir Araştırma. Doktora Tezi. İstanbul Aydın Üniversitesi, SBE, İşletme ABD, İstanbul.

Falkenburg, K. \& Schyns, B. (2007). Work Satisfaction, Organizational Commitment and Withdrawal Behaviors. Management Research News, 30(10), 708-723.

Forbes. 03.10.2019. "Global 2000: The World's Best Employers", https://www.forbes.com/lists/worlds-bestemployers/\#ce3f7ff1e0ca, Erişim Tarihi: 10.02.2020. 


\section{F. K. Şentürk - M. Ertem 13/1 (2021) 760-771}

Fritz, M.S. \& MacKinnon, D.P. (2007). Required sample size to detect the mediated effect. Psychological Science, $18,233-239$.

Furtmueller, E., Van Dick, R. \& Wilderom, C.P. (2011). On the illusion of organizational commitment among finance professionals. Team Performance Management, 17(5/6), 255-278.

Gomes, D.R. (2009). Organizational change and job satisfaction: The mediating role of organizational commitment. Exedra: Revista Científica, (1), 177-195.

Gürbüz, S. (2019). Sosyal Bilimlerde Aracı, Düzenleyici ve Durumsal Etki Analizleri. Ankara: Seçkin Yayınları.

Gürbüz, S. \& Bekmezci, M. (2012). İnsan Kaynakları Yönetimi Uygulamalarının Bilgi İşçilerinin İşten Ayrılma Niyetine Etkisinde Duygusal Bağlllı̆ın Aracılık Ve Düzenleyicilik Rolü. İstanbul Üniversitesi İşletme Fakültesi Dergisi, 41(2): 189-213.

Hackman, J.R. \& Oldham, G.R. (1975). Development of the Job Diagnostic Survey. Journal of Applied Psychology. 60: 159-170.

Hayes, A.F. \& Rockwood, N.J. (2017). Regression-based statistical mediation and moderation analysis in clinical research: Observations, recommendations, and implementation. Behavior Research and Therapy, 98, 39-57.

Hayes, A.F. (2018). Introduction to Mediation, Moderation, and Conditional Process Analysis: A Regression-Based Approach. 2nd Edition. New York: Guilford Publications.

Herscovitch, L., \& Meyer, J. P. (2002). Commitment to Organizational Change: Extension of A ThreeComponent Model. Journal of Applied Psychology, 87(3): 474-487.

Holt, D.T., Armenakis, A.A., Feild, H.S. \& Harris, S.G. (2007). Readiness for organizational change: The systematic development of a scale. The Journal of Applied Behavioral Science, 43(2): 232-255.

Jaros, S. (2010). Commitment to Organizational Change: A Critical Review. Journal of Change Management, 10(1), 79-108.

İmamoğlu, E.B. \& Turan, A.D. (2019). Güçlendirici liderlik ile bilgi paylaşımı davranışı arasındaki ilişkide algılanan örgütsel desteğin aracı rolü: Bilişim sektöründe bir araştırma. Istanbul Management Journal, 87: 27-48.

Karagöz, Y. (2014). SPSS 21.1 Uygulamalı Biyoistatistik. Ankara: Nobel Akademik Yayıncllı.

Keser, A. \& Kümbül Güler. (2016). Çalışma Psikolojisi. Kocaeli: Umuttepe Yayınları.

Koç, F., Kaya, N., Özbek, V., \& Akkılıç, M. E. (2014). Algılanan Fiyat İle Tüketici Güveni Arasında Algılanan Hizmet Kalitesinin Aracı Etkisi: Bankacılık Ve GSM Sektörlerinin Karşılaştırılmasına Yönelik Bir Araştırma. Pazarlama ve Pazarlama Araştırmaları Dergisi, Sayı: 13: 1-26.

Koçel, T. (2005). İşletme Yöneticiliği. 10. Baskı. İstanbul: Arıkan Yayınları.

Lines, R. (2004). Influence of participation in strategic change: resistance, organizational commitment and change goal achievement. Journal of Change Management, 4(3): 193-215.

Meyer, J.P. \& Allen, N.J. (1991). A Three-Component Conceptualization of Organizational Commitment. Human Resource Management Review, 1(1): 61-89.

Meyer, J.P., Allen, N.J. \& Smith, C.A. (1993). Commitment to Organizations and Occupations: Extension and Test of a Three Component Conceptualization. Journal of Applied Psychology, 78(4): 538-551.

Meyer, J.P., Irving, P.G. \& Allen, N.J. (1998). Examination of the Combined Effects of Work Values and Early Work Experiences on Organizational Commitment. Journal of Organizational Behavior, Vol.19: 29-52.

Meyer, J.P., Srinivas, E.S., Lal, J.B. \& Topolnytsky, L. (2007). Employee Commitment and Support for An Organizational Change: Test of the Three-Component Model in Two Cultures. Journal of Occupational and Organizational Psychology, 80(2): 185-211. 


\section{F. K. Şentürk - M. Ertem 13/1 (2021) 760-771}

Mowday, R. T., Steers, R. M., \& Porter, L. W. (1979). The measurement of organizational commitment. Journal of vocational behavior, 14(2), 224-247.

Olağanüstü Hal Kapsamında Bazı Düzenlemeler Yapılması Hakkında Kanun Hükmünde Kararname (2017, 25 Ağustos). Resmi Gazete (Sayl: 30165 (Mükerrer). Erişim Adresi: https://www.resmigazete.gov.tr/eskiler/2017/08/20170825-13.pdf.

Özbek, V., Alnıaçık, Ü., Koç, F., Akkılıç, M.E. \& Kaş, E. (2014). Kişilik özelliklerinin teknoloji kabulü üzerindeki doğrudan ve dolaylı etkileri: Akıllı telefon teknolojileri üzerine bir araştırma. International Review of Economics and Management, 2(1), 36-57.

Özdamar, K. (1999). Paket Programlar İle İstatistiksel Veri Analizi. Eskişehir: Kaan Kitabevi.

Özkalp, E. \& Kırel, Ç. (2005). Örgütsel Davranış. Eskişehir: Anadolu Üniversitesi Yayınları.

Parish, J. T., Cadwallader, S., \& Busch, P. (2008). Want to, need to, ought to: employee commitment to organizational change. Journal of organizational change management, 21(1), 32-52.

Porter, L.W., Steers, R.M. \& Boulian, P.V. (1973). Organizational Commitment, Job Satisfaction, and Turnover among Psychiatric Technicians. US Department of Health, Education \& Welfare National Institute of Education, Technical Report, No:16, 1-24.

Preacher, K.J. \& Hayes, A.F. (2004). SPSS and SAS procedures for estimating indirect effects in simple mediation models. Behavior Research Methods, Instruments, and Computers, 36, 717-731.

Preacher, K.J. \& Kelly, K. (2011). Effect size measures for mediation models: Quantitative strategies for communicating indirect effects. Psychological Methods, 16, 93-115.

Rafferty, A.E. \& Griffin, M.A. (2006). Perceptions of organizational change: A stress and coping perspective. Journal of Applied Psychology, 91(5), 1154.

Reid, M.F., Riemenschneider, C.K., Allen, M.W. \& Armstrong, D.J. (2008). Information Technology Employees in State Government: A Study of Affective Organizational Commitment, Job Involvementi and Job Satisfaction. The American Review of Public Administration. 38(1), 41-61.

Robbins, S.P. \& Judge, T.A. (2013). Örgütsel Davranış. 14. Baskı. Çev. Edit. İnci Erdem. Ankara: Nobel Yayınları.

Sağlık Bakanlığı Ve Bağlı Kuruluşlarının Teşkilat Ve Görevleri Hakkında Kanun Hükmünde Kararname (2011, 2 Kasım). Resmi Gazete (Sayı 28103 (Mükerrer)). Erişim Adresi: https://www.resmigazete.gov.tr/eskiler/2011/11/20111102M1-3.htm.

Schein, E.H. (1980). Organizational Psychology, 3rd Edition. Englewood Cliffs-NJ: Prentice-Hall.

Sezgin, A.B., Tolay, E. \& Sürgevil, O. (2016). Örgütsel Değiş̧im Sinizmi: Çalışanların Değişime Karşı Tutumlarının İncelenmesine Yönelik Nitel Bir Araştırma. Marmara Üniversitesi Öneri Dergisi, 12(45): 411438.

Shin, J., Seo, M. G., Shapiro, D. L., \& Taylor, M. S. (2015). Maintaining employees' commitment to organizational change: The role of leaders' informational justice and transformational leadership. The Journal of Applied Behavioral Science, 51(4), 501-528.

Spector, P.E. (1997). Job Satisfaction: Application, Assessment, Causes, and Consequences. Thousand Oaks, CA. Sage Publications.

Şeşen, H. \& Basım, H.N. (2010). Çalışanların Adalet Algısının Örgütsel Vatandaşlık Davranışlarına Etkisi: İş Tatmininin Aracılık Rolü. ODTÜ Gelişme Dergisi. 37, 171-193.

Şevik, Ü. (2019). Algılanan Örgütsel Politika İle Pozitif Psikolojik Sermayenin İş Tatmini, İşten Ayrılma Niyeti Ve Örgütsel Sessizlik Üzerine Etkisi: Afyonkarahisar Örneği. Doktora Tezi. Sakarya Üniversitesi, İşletme Enstitüsü, Yön. ve Org. ABD, Sakarya.

TLA (Turkish Language Association). (2020). Değişim. https://sozluk.gov.tr/, Erişim Tarihi: 06.02.2020.

Toffler, A. (2018). Üçüncü Dalga - Bir Fütürist Ekonomi Analizi Klasiği. Çev. Selim Yeniçeri. İstanbul: Koridor Yayıncilik. 
F. K. Şentürk - M. Ertem 13/1 (2021) 760-771

Toprak, M. \& Aydın, T. (2015). Değişime Bağlılık Ölçeğinin Türkçeye Uyarlanması Çalışması. Electronic International Journal of Education, Arts, and Science, 1(1), 35-54.

Tunçer, P. (2013). Değişim Yönetimi Sürecinde Değişime Direnme. Ondokuz Mayıs Üniversitesi Ĕ̆itim Fakültesi Dergisi, 32(1), 373-406.

Weiner, B.J. (2009). A theory of organizational readiness for change. Implementation Science, 4(1), 67-75.

Wulandari, P., Mangundjaya, W. \& Utoyo, D.B. (2015). Is job satisfaction a moderator or mediator on the relationship between change leadership and commitment to change. Procedia-Social and Behavioral Sciences, 172, 104-111.

Valaei, N. \& Rezaei, S. (2016). Job satisfaction and organizational commitment: An empirical investigation among ICT-SMEs. Management Research Review, 39(12), 1663-1694.

Yousef, D.A. (2000). Organizational commitment and job satisfaction as predictors of attitudes toward organizational change in a non-western setting. Personnel Review, 29(5), 567-592.

Zincirkıran, M. \& Keser, A. (2018). Örgütsel Davranıs. Bursa: Dora Basım Yayın. 